\title{
Intuitionistic Q-fuzzy Ideals of BG-Algebra
}

\author{
S.R.Barbhuiya \\ Department of Mathematics, Srikishan Sarda College, Hailakandi, \\ Hailakandi-788151, Assam, India
}

\begin{abstract}
The concept of intuitionistic fuzzy subset was introduced by K.T.Atanassov and the notion of intuitionistic fuzzy ideals of BG-algebra was developed by A.Zarandi and A.Borumand Saeid in 2005. In this paper, for a set Q, the notion of intuitionistic Q-fuzzy ideals of BG-algebra is introduce and investigate some of their basic properties.
\end{abstract}

AMS Subject Classification (2010):06F35, 03G25, 03E72.

\section{Keywords}

BG-algebra, subalgebra, Q-fuzzy set, intuitionistic Q-fuzzy set, intuitionistic Q-fuzzy ideal.

\section{INTRODUCTION}

In 1965 ,Zadeh [1] introduced the notion of a fuzzy subset of a set as method of representing uncertainty in real physical world. As a generalization of this, intuitionistic fuzzy subset was defined by K.T.Atanassov [2] in 1986. Fuzzy sets give the degree of membership of an element in a given set, while intuitionistic fuzzy sets give both a degree of membership and a degree of non membership. Goguen [3] generalised the notion of fuzzy subset of $\mathrm{X}$ to that of an L-fuzzy subset namely a function from $X$ to a lattice L. R.Muthuraj et al [4] introduced the notion of Q-fuzzy set. K.H.Kim[5] studied intuitionistic Q-fuzzy ideals. In 1966 Imai and Iseki [6] introduced the two classes of abstract algebras viz.BCKalgebras and BCI-algebras. It is known that the class of BCK -algebra is a proper sub class of the class of BCI-algebras. Neggers and Kim [7] introduced a new notion, called Balgebras which is related to several classes of algebras such as BCI/BCK-algebras. C.B.Kim and H.S.Kim [8] introduced the notion of BG-algebra which is a generalisation of B-algebra. Zarandi and Borumand saeid [9] developed intuitionistic fuzzy ideal of BG-algebra.Senapati,T.et al [10] studied intuitionistic fuzzy ideals in BG-algebras in 2012. Motivated by this we have introduce the notion of Intuitionistic Q-fuzzy ideals of BG-algebra and establish some of their basic properties.

\section{PRELIMINARIES}

\section{Definition 2.1}

A BG-algebra is a non-empty set $\mathrm{X}$ with a constant 0 and a binary operation $*$ satisfying the following axioms.

$$
\begin{array}{ll}
\text { (i) } & \mathrm{x} * \mathrm{x}=0 \\
\text { (ii) } & \mathrm{x} * 0=\mathrm{x} \\
\text { (iii) } & (\mathrm{x} * \mathrm{y}) *(0 * \mathrm{y})=\mathrm{x} \text { for all } \mathrm{x}, \mathrm{y} \in \mathrm{X}
\end{array}
$$

For brevity we also call X a BG-algebra.

\section{Example 2.1}

Let $X=\{0,1,2,3,4\}$ with the following cayley table

\begin{tabular}{|l|l|l|l|l|l|}
\hline$*$ & 0 & 1 & 2 & 3 & 4 \\
\hline 0 & 0 & 4 & 3 & 2 & 1 \\
\hline 1 & 1 & 0 & 4 & 3 & 2 \\
\hline 2 & 2 & 1 & 0 & 4 & 3 \\
\hline 3 & 3 & 2 & 1 & 0 & 4 \\
\hline 4 & 4 & 3 & 2 & 1 & 0 \\
\hline
\end{tabular}

Then $(\mathrm{X}, *, 0)$ is a $\mathrm{BG}$ algebra .

We define a partial ordering $\mathrm{x} \leq \mathrm{y}$ if and only if $\mathrm{x} * \mathrm{y}=0$.

Definition 2.2

A non-empty subset $\mathrm{S}$ of a BG-algebra $\mathrm{X}$ is called a subalgebra of $X$ if $x * y \in S$, for all $x, y \in S$.

\section{Definition 2.3}

A nonempty subset I of a BG-algebra X is called BG-ideal of $\mathrm{X}$ if

(i) $0 \in I$

(ii) $\mathrm{x} * \mathrm{y} \in \mathrm{I}$ and $\mathrm{y} \in \mathrm{I} \Rightarrow \mathrm{x} \in \mathrm{I}$ for all $\mathrm{x}, \mathrm{y} \in \mathrm{X}$.

\section{Definition 2.4}

An Ideal I of $X$ is called closed if $0 * x \in I, \forall x \in I$.

\section{Definition 2.5}

A fuzzy subset $\mu$ of $X$ is called a fuzzy subal-gebra of a BGalgebra $X$ if $\mu(x * y) \geq \min \{\mu(x), \mu(y)\}$ for all $x, y \in X$.

\section{Definition 2.6}

Let $Q$ and $G$ be any two sets. A mapping $f: G \times Q \rightarrow[0,1]$ is called a Q-fuzzy set in G.

\section{Definition 2.7}

Let $\mu$ be a Q-fuzzy set in $X$. For $t \in[0,1]$, the set $\mu_{\mathrm{t}}=\{\mathrm{x} \in \mathrm{X} \mid \mu(\mathrm{x}, \mathrm{q}) \geq \mathrm{t} \forall \mathrm{q} \in \mathrm{Q}\}$ is called a level subset of $\mu$.

\section{Definition 2.8}

If $\mu$ be a Q-fuzzy set in X. Then the complement of $\mu$ is denoted by $\mu^{c}$ is the Q-fuzzy subset of $X$ given by $\mu^{c}(x, q)=1-\mu(x, q) \forall$ $\mathrm{x} \in \mathrm{X}$ and $\mathrm{q} \in \mathrm{Q}$.

\section{Definition 2.9}

Let $\mu$ be a Q-fuzzy set in BG-algebra X. then $\mu$ is called Qfuzzy subalgebra of $\mathrm{X}$ if

$\mu(x * y, q) \geq \min \{\mu(x, q), \mu(y, q)\} \forall x, y \in X, q \in Q$. 


\section{Definition 2.10}

A Q-fuzzy set $\mu$ in $\mathrm{X}$ is called a Q-fuzzy BG-ideal of $\mathrm{X}$ if it satisfies the following conditions.
(i) $\mu(0, q) \geq \mu(x, q)$
(ii) $\mu(\mathrm{x}, \mathrm{q}) \geq \min \{\mu(\mathrm{x} * \mathrm{y}, \mathrm{q}), \mu(\mathrm{y}, \mathrm{q})\} \quad \forall \mathrm{x}, \mathrm{y} \in \mathrm{X}, \mathrm{q} \in \mathrm{Q}$.

\section{Definition 2.11}

An intuitionistic fuzzy set (IFS) A of a BG-algebra $\mathrm{X}$ is an object of the form $A=\left\{\left\langle x, \mu_{A}(x), v_{A}(x)\right\rangle \mid x \in X\right\}$ where $\mu_{A}$ : $\mathrm{X} \rightarrow[0,1]$ and $v_{\mathrm{A}}: \mathrm{X} \rightarrow[0,1]$ with the condition $0 \leq \mu_{\mathrm{A}}(\mathrm{X})+$ $v_{\mathrm{A}}(\mathrm{x}) \leq 1, \forall \mathrm{x} \in \mathrm{X}$. The numbers $\mu_{\mathrm{A}}(\mathrm{x})$ and $v_{\mathrm{A}}(\mathrm{x})$ denote respectively the degree of membership and the degree of non membership of the element $\mathrm{x}$ in the set A. For the sake of simplicity, we shall use the symbol $A=\left(\mu_{A}, v_{A}\right)$ for the intuitionistic fuzzy set $\mathrm{A}=\left\{\left\langle\mathrm{x}, \mu_{\mathrm{A}}(\mathrm{x}), v_{\mathrm{A}}(\mathrm{x})\right\rangle \mid \mathrm{x} \in \mathrm{X}\right\}$.

\section{Definition 2.12}

An intuitionistic Q-fuzzy set (IQFS) A of a BG-algebra $X$ is an object of the form $A=\left\{<x, \mu_{A}(x, q), v_{A}(x, q)>\mid x \in X, q\right.$ $\in \mathrm{Q}\}$ where $\mu_{\mathrm{A}}: \mathrm{X} \times \mathrm{Q} \rightarrow[0,1]$ and $v_{\mathrm{A}}: \mathrm{X} \times \mathrm{Q} \rightarrow[0,1]$ with the condition $0 \leq \mu_{\mathrm{A}}(\mathrm{x}, \mathrm{q})+v_{\mathrm{A}}(\mathrm{x}, \mathrm{q}) \leq 1, \forall \mathrm{x} \in \mathrm{X}$. The numbers $\mu_{\mathrm{A}}(\mathrm{x}, \mathrm{q})$ and $v_{\mathrm{A}}(\mathrm{x}, \mathrm{q})$ denote respectively the degree of membership and the degree of non membership of the element $\mathrm{x}$ in the set $\mathrm{A}$. For the sake of simplicity, we shall use the symbol $\mathrm{A}=\left(\mu_{\mathrm{A}}, v_{\mathrm{A}}\right)$ for the intuitionistic Q-fuzzy set $\mathrm{A}=$ $\left\{<\mathrm{x}, \mu_{\mathrm{A}}(\mathrm{x}, \mathrm{q}), v_{\mathrm{A}}(\mathrm{x}, \mathrm{q}) \mid \mathrm{x} \in \mathrm{X}, \mathrm{q} \in \mathrm{Q}\right.$.

\section{Definition 2.13}

An intuitionistic Q-fuzzy set (IQFS) A of a BG-algebra $\mathrm{X}$ is said to be an intuitionistic Q-fuzzy BG-subalgebra X if.

$$
\begin{aligned}
& \mu_{\mathrm{A}}(\mathrm{x} * \mathrm{y}, \mathrm{q}) \geq \min \left\{\mu_{\mathrm{A}}(\mathrm{x}, \mathrm{q}), \mu_{\mathrm{A}}(\mathrm{y}, \mathrm{q})\right\} \\
& v_{\mathrm{A}}(\mathrm{x} * \mathrm{y}, \mathrm{q}) \leq \max \left\{v_{\mathrm{A}}(\mathrm{x}, \mathrm{q}), v_{\mathrm{A}}(\mathrm{y}, \mathrm{q})\right\} \forall \mathrm{x}, \mathrm{y} \in \mathrm{X}, \mathrm{q} \in \mathrm{Q} .
\end{aligned}
$$$$
\text { (ii) }
$$

\section{Example 2.2}

Consider BG-algebra $X=\{0,1,2\}$ with the following cayley table.

\begin{tabular}{|c|c|c|c|}
\hline$*$ & 0 & 1 & 2 \\
\hline 0 & 0 & 1 & 2 \\
\hline 1 & 1 & 0 & 1 \\
\hline 2 & 2 & 2 & 0 \\
\hline
\end{tabular}

The intuitionistic Q-fuzzy subset $A=\left\{<x, \mu_{A}(x, q), v_{A}(x, q)\right.$ $>\mid x \in X, q \in Q$ \}given by $\mu_{A}(0, q)=\mu_{A}(1, q)=0.6, \mu_{A}(2, q)=$ 0.2 and $v_{\mathrm{A}}(0, \mathrm{q})=v_{\mathrm{A}}(1, \mathrm{q})=0.3, v_{\mathrm{A}}(2, \mathrm{q})=0.5$ is an intuitionistic Q-fuzzy BG-subalgebra X.

\section{INTUITIONISTIC Q-FUZZY IDEAL OF BG-ALGEBRA}

\section{Definition 3.1}

An intuitionistic Q-fuzzy set A of a BG-algebra X is said to be an intuitionistic Q-fuzzy ideal of $\mathrm{X}$ if.
(i) $\quad \mu_{\mathrm{A}}(0, \mathrm{q}) \geq \mu_{\mathrm{A}}(\mathrm{x}, \mathrm{q})$
(ii) $\quad v_{\mathrm{A}}(0, \mathrm{q}) \leq v_{\mathrm{A}}(\mathrm{x}, \mathrm{q})$
(iii) $\quad \mu_{\mathrm{A}}(\mathrm{x}, \mathrm{q}) \geq \min \left\{\mu_{\mathrm{A}}(\mathrm{x} * \mathrm{y}, \mathrm{q}), \mu_{\mathrm{A}}(\mathrm{y}, \mathrm{q})\right\}$
(iv) $\quad v_{\mathrm{A}}(\mathrm{x}, \mathrm{q}) \leq \max \left\{v_{\mathrm{A}}\left(\mathrm{x}^{*} \mathrm{y}, \mathrm{q}\right), v_{\mathrm{A}}(\mathrm{y}, \mathrm{q})\right\} \quad \forall \mathrm{x}, \mathrm{y} \in \mathrm{X}, \mathrm{q} \in \mathrm{Q}$.

\section{Example 3.1}

Consider BG-algebra $X=\{0,1,2,3\}$ with the following cayley table.

\begin{tabular}{|l|l|l|l|l|}
\hline$*$ & 0 & 1 & 2 & 3 \\
\hline 0 & 0 & 1 & 2 & 3 \\
\hline 1 & 1 & 0 & 1 & 1 \\
\hline 2 & 2 & 2 & 0 & 2 \\
\hline 3 & 3 & 3 & 3 & 0 \\
\hline
\end{tabular}

The intuitionistic Q-fuzzy subset $A=\left\{<x, \mu_{A}(x, q), v_{A}(x, q) \mid x\right.$ $\in X, q \in Q$ \} given by $\mu_{A}(0, q)=1, \mu_{A}(1, q)=\mu_{A}(2, q)=\mu_{A}(3$, q) $=0.3$ and $v_{\mathrm{A}}(0, \mathrm{q})=0, v_{\mathrm{A}}(1, \mathrm{q})=v_{\mathrm{A}}(2, \mathrm{q})=v_{\mathrm{A}}(3, \mathrm{q})=0.4$ then $\mathrm{A}$ is an intuitionistic Q-fuzzy ideal of BG-algebra X.

\section{Definition 3.2}

An intuitionistic Q-fuzzy set A of a BG-algebra X is said to be an intuitionistic Q-fuzzy closed ideal of $\mathrm{X}$ if.
(i) $\quad \mu_{\mathrm{A}}(\mathrm{x}, \mathrm{q}) \geq \min \left\{\mu_{\mathrm{A}}(\mathrm{x} * \mathrm{y}, \mathrm{q}), \mu_{\mathrm{A}}(\mathrm{y}, \mathrm{q})\right\}$
(ii) $\quad v_{\mathrm{A}}(\mathrm{x}, \mathrm{q}) \leq \max \left\{v_{\mathrm{A}}(\mathrm{x} * \mathrm{y}, \mathrm{q}), v_{\mathrm{A}}(\mathrm{y}, \mathrm{q})\right\}$
(iii) $\quad \mu_{\mathrm{A}}(0 * \mathrm{x}, \mathrm{q}) \geq \mu_{\mathrm{A}}(\mathrm{x}, \mathrm{q})$
(iv) $\quad v_{\mathrm{A}}(0 * \mathrm{x}, \mathrm{q}) \leq v_{\mathrm{A}}(\mathrm{x}, \mathrm{q}) \forall \mathrm{x}, \mathrm{y} \in \mathrm{X}, \mathrm{q} \in \mathrm{Q}$.

\section{Example 3.2}

Consider BG-algebra $X=\{0,1,2,3\}$ with the same cayley table as in example 3.1,the intuitionistic Q-fuzzy subset $\mathrm{A}=$ $\left\{<\mathrm{x}, \mu_{\mathrm{A}}(\mathrm{x}, \mathrm{q}), v_{\mathrm{A}}(\mathrm{x}, \mathrm{q}) \mid \mathrm{x} \in \mathrm{X}, \mathrm{q} \in \mathrm{Q}\right\}$ given by $\mu_{\mathrm{A}}(0, \mathrm{q})=1$, $\mu_{\mathrm{A}}(1, \mathrm{q})=0.6, \mu_{\mathrm{A}}(2, \mathrm{q})=\mu_{\mathrm{A}}(3, \mathrm{q})=0.3$ and $v_{\mathrm{A}}(0, \mathrm{q})=0.1$, $v_{A}(1, q)=0.3, v_{A}(2, q)=v_{A}(3, q)=0.5$ then $A$ is an intuitionistic Q-fuzzy closed ideal of BG-algebra X.

\section{Proposition 3.1}

Every intuitionistic Q-fuzzy closed ( IQFC) ideal is an intuitionistic Q-fuzzy ideal.

Proof. Let $A=\left(\mu_{A}, v_{A}\right)$ is an intuitionistic Q-fuzzy closed ( IQFC) ideal of $X$, to prove that $A$ is an intuitionistic Q-fuzzy ideal. It is enough to show that $\mu_{\mathrm{A}}(0, \mathrm{q}) \geq \mu_{\mathrm{A}}(\mathrm{x}, \mathrm{q})$ and $v_{\mathrm{A}}(0$, $\mathrm{q}) \leq v_{\mathrm{A}}(\mathrm{x}, \mathrm{q})$ Now $\mu_{\mathrm{A}}(0, \mathrm{q}) \geq \min \left\{\mu_{\mathrm{A}}(0 * \mathrm{x}, \mathrm{q}), \mu_{\mathrm{A}}(\mathrm{x}, \mathrm{q})\right\} \geq$ $\mu_{\mathrm{A}}(\mathrm{x}, \mathrm{q})$ since $\mu_{\mathrm{A}}(0 * \mathrm{x}, \mathrm{q}) \geq \mu_{\mathrm{A}}(\mathrm{x}, \mathrm{q})$ similarly it can be shown that $v_{\mathrm{A}}(0, \mathrm{q}) \leq v_{\mathrm{A}}(\mathrm{x}, \mathrm{q})$.

\section{Remark 3.1}

The converse of above proposition is not true in general.

\section{Proposition 3.2}

If $A$ is an intuitionistic Q-fuzzy ideal of $X$ with $x \leq y$ for any $\mathrm{x}, \mathrm{y} \in \mathrm{X}$, then $\mu_{\mathrm{A}}(\mathrm{x}, \mathrm{q}) \geq \mu_{\mathrm{A}}(\mathrm{y}, \mathrm{q})$ and $v_{\mathrm{A}}(\mathrm{x}, \mathrm{q}) \leq v_{\mathrm{A}}(\mathrm{y}, \mathrm{q})$ i.e. $\mu_{\mathrm{A}}$ is order reversing and $v_{\mathrm{A}}$ is order preserving.

Proof. Let $\mathrm{x}, \mathrm{y} \in \mathrm{X}$ such that $\mathrm{x} \leq \mathrm{y}$ then by partial ordering $\leq$ defined in $X$, we have $\mathrm{x} * \mathrm{y}=0$, thus

$$
\begin{aligned}
& \begin{aligned}
\mu_{\mathrm{A}}(\mathrm{x}, \mathrm{q}) & \geq \min \left\{\mu_{\mathrm{A}}(\mathrm{x} * \mathrm{y}, \mathrm{q}), \mu_{\mathrm{A}}(\mathrm{y}, \mathrm{q})\right\} \\
& =\min \left\{\mu_{\mathrm{A}}(0, \mathrm{q}), \mu_{\mathrm{A}}(\mathrm{y}, \mathrm{q})\right\} \\
& =\mu_{\mathrm{A}}(\mathrm{y}, \mathrm{q}) \quad\left[\operatorname{Since} \mu_{\mathrm{A}}(0, \mathrm{q}) \geq \mu_{\mathrm{A}}(\mathrm{x}, \mathrm{q}) \forall \mathrm{x} \in \mathrm{Q}\right]
\end{aligned} \\
& \text { And } \\
& \begin{aligned}
& v_{\mathrm{A}}(\mathrm{x}, \mathrm{q}) \leq \max \left\{v_{\mathrm{A}}(\mathrm{x} * \mathrm{y}, \mathrm{q}), v_{\mathrm{A}}(\mathrm{y}, \mathrm{q})\right\} \\
&=\max \left\{v_{\mathrm{A}}(0, \mathrm{q}), v_{\mathrm{A}}(\mathrm{y}, \mathrm{q})\right\} \\
&=v_{\mathrm{A}}(\mathrm{y}, \mathrm{q}) \quad\left[\operatorname{since} v_{\mathrm{A}}(0, \mathrm{q}) \leq v_{\mathrm{A}}(\mathrm{y}, \mathrm{q}) \forall \mathrm{y} \in \mathrm{X}\right]
\end{aligned}
\end{aligned}
$$




\section{Proposition 3.3}

If $\mathrm{A}$ is an intuitionistic Q-fuzzy ideal of $\mathrm{X}$ with $\mathrm{x} * \mathrm{y} \leq \mathrm{z}$ for all $\mathrm{x}, \mathrm{y}, \mathrm{z} \in \mathrm{X}$,then

$\mu_{\mathrm{A}}(\mathrm{x}, \mathrm{q}) \geq \min \left\{\mu_{\mathrm{A}}(\mathrm{y}, \mathrm{q}), \mu_{\mathrm{A}}(\mathrm{z}, \mathrm{q})\right\}$

$v_{\mathrm{A}}(\mathrm{x}, \mathrm{q}) \leq \max \left\{v_{\mathrm{A}}(\mathrm{y}, \mathrm{q}), v_{\mathrm{A}}(\mathrm{z}, \mathrm{q})\right\}$

Proof Let $\mathrm{x}, \mathrm{y}, \mathrm{z} \in \mathrm{X}$ such that $\mathrm{x} * \mathrm{y} \leq \mathrm{z}$

therefore $(\mathrm{x} * \mathrm{y}) * \mathrm{z}=0$, Now

$\mu_{A}(x, q) \geq \min \left\{\mu_{A}(x * y, q), \mu_{A}(y, q)\right\}$

$$
\begin{aligned}
& \geq \min \left\{\min \left\{\mu_{A}(((x * y) * z), q), \mu_{A}(z, q)\right\}, \mu_{A}(y, q)\right\} \\
& =\min \left\{\min \left\{\mu_{A}(0, q), \mu_{A}(z, q)\right\}, \mu_{A}(y, q)\right\} \\
& =\min \left\{\mu_{A}(z, q), \mu_{A}(y, q)\right\}
\end{aligned}
$$

[Since $\mu_{\mathrm{A}}(0, \mathrm{q}) \geq \mu_{\mathrm{A}}(\mathrm{z}, \mathrm{q}) \forall \mathrm{z} \in \mathrm{Q}$ ]

Similarly

$$
\begin{aligned}
v_{\mathrm{A}}(\mathrm{x}, \mathrm{q}) \leq & \max \left\{v_{\mathrm{A}}(\mathrm{x} * \mathrm{y}, \mathrm{q}), v_{\mathrm{A}}(\mathrm{y}, \mathrm{q})\right\} \\
\geq & \max \left\{\max \left(v_{\mathrm{A}}((\mathrm{x} * \mathrm{y}) * \mathrm{z}), \mathrm{q}\right), v_{\mathrm{A}}(\mathrm{z}, \mathrm{q}), v_{\mathrm{A}}(\mathrm{y}, \mathrm{q})\right\} \\
= & \max \left\{\max \left(v_{\mathrm{A}}(0, \mathrm{q}), v_{\mathrm{A}}(\mathrm{z}, \mathrm{q}), v_{\mathrm{A}}(\mathrm{y}, \mathrm{q})\right\}\right. \\
= & \max \left\{v_{\mathrm{A}}(\mathrm{z}, \mathrm{q}), v_{\mathrm{A}}(\mathrm{y}, \mathrm{q})\right\} \\
& {\left[\text { since } v_{\mathrm{A}}(0, \mathrm{q}) \leq v_{\mathrm{A}}(\mathrm{z}, \mathrm{q}) \forall \mathrm{z} \in \mathrm{X}\right] }
\end{aligned}
$$

\section{Theorem 3.1}

If $A$ is an intuitionistic Q-fuzzy ideal of $X$,then for any $x, a_{1}$, $a_{2}, a_{2} a_{n} \in X$ and $\left(\ldots\left(\left(x * a_{1}\right) * a_{2}\right) * \ldots\right) * a_{n}=0$ implies $\mu_{A}(x, q)$ $\geq \min \left\{\mu_{\mathrm{A}}\left(\mathrm{a}_{1}, \mathrm{q}\right), \mu_{\mathrm{A}}\left(\mathrm{a}_{2}, \mathrm{q}\right), \ldots \mu_{\mathrm{A}}\left(\mathrm{a}_{\mathrm{n}}, \mathrm{q}\right)\right\}$ and $v_{\mathrm{A}}(\mathrm{x}, \mathrm{q}) \leq$ $\max \left\{v_{\mathrm{A}}\left(\mathrm{a}_{1}, \mathrm{q}\right), v_{\mathrm{A}}\left(\mathrm{a}_{2}, \mathrm{q}\right), \ldots v_{\mathrm{A}}\left(\mathrm{a}_{\mathrm{n}}, \mathrm{q}\right)\right\}$.

\section{Theorem 3.2}

Intersection of any two intuitionistic Q-fuzzy ideal of $\mathrm{X}$ is also an intuitionistic Q-fuzzy ideal.

Proof. Let $A=\left\{\left\langle x, \mu_{A}(x, q), v_{A}(x, q)>\right| x \in X, q \in Q\right\}$ and $B$ $=\left\{\left\langle\mathrm{x} \mu_{\mathrm{B}}(\mathrm{x}, \mathrm{q}), v_{\mathrm{B}}(\mathrm{x}, \mathrm{q})\right\rangle \mid \mathrm{x} \in \mathrm{X}, \mathrm{q} \in \mathrm{Q}\right\}$ be two intuitionistic Q-fuzzy ideal of $X$.

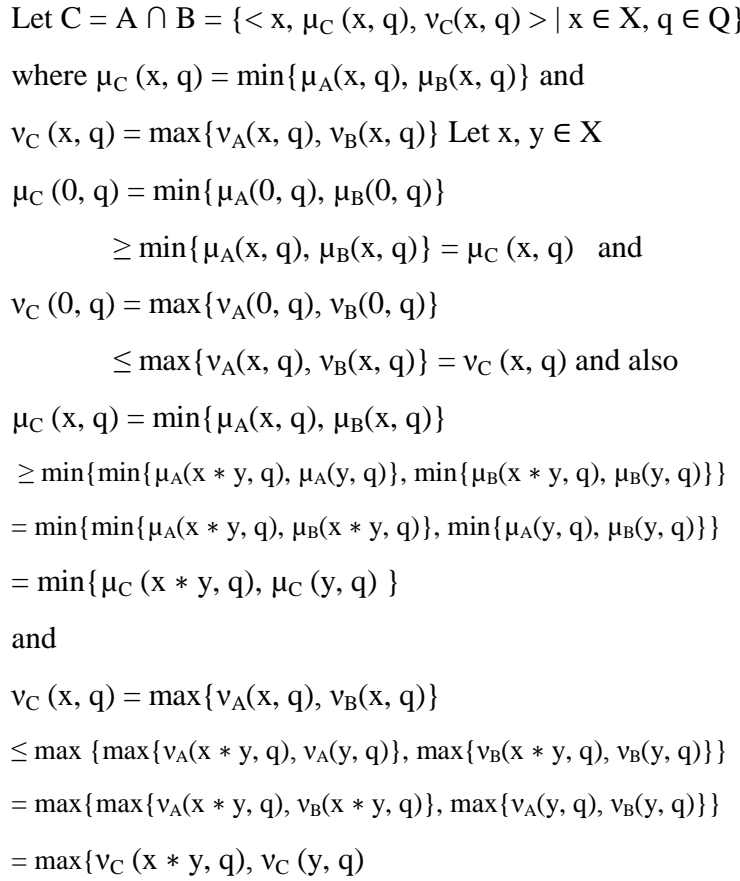

Hence $\mathrm{C}$ is an intuitionistic Q-fuzzy ideal.

The above theorem can be generalized as follows.

\section{Theorem 3.3}

Intersection of a family of intuitionistic Q-fuzzy ideal of $\mathrm{X}$ is also an intuitionistic Q-fuzzy ideal of X.

\section{Theorem 3.4}

Intersection of any two intuitionistic Q-fuzzy closed ideal of $\mathrm{X}$ is also an intuitionistic Q-fuzzy closed ideal more generally intersection of a family of intuitionistic Q-fuzzy closed ideal of $\mathrm{X}$ is also an intuitionistic Q-fuzzy closed ideal of X.

\section{Theorem 3.5}

An IQFS $A=\left\{\left\langle x, \mu_{A}(x, q), v_{A}(x, q)\right\rangle \mid x \in X, q \in Q\right\}$ is an IQF ideal of $X$,then the sets

$X_{\mu}=\left\{x \in X \mid \mu_{A}(x, q)=\mu_{A}(0, q), q \in Q\right\}$

$X_{v}=\left\{x \in X \mid v_{A}(x, q)=v_{A}(0, q), q \in Q\right\}$ are ideals of $X$.

Proof. Clearly $0 \in \mathrm{X}_{\mu}$

Let $\mathrm{x} * \mathrm{y}, \mathrm{y} \in \mathrm{X}_{\mu}$

Therefore $\mu_{\mathrm{A}}(\mathrm{x} * \mathrm{y}, \mathrm{q})=\mu_{\mathrm{A}}(0, \mathrm{q})=\mu_{\mathrm{A}}(\mathrm{y}, \mathrm{q})$

Since $\mathrm{A}$ is an IQFI of $\mathrm{X}$

Therefore $\mu_{\mathrm{A}}(\mathrm{x}, \mathrm{q}) \geq \min \left\{\mu_{\mathrm{A}}(\mathrm{x} * \mathrm{y}, \mathrm{q}), \mu_{\mathrm{A}}(\mathrm{y}, \mathrm{q})\right\}$

$$
\begin{aligned}
& \geq \min \left\{\mu_{A}(0, q), \mu_{A}(0, q)\right\} \\
& =\mu_{A}(0, q)
\end{aligned}
$$

Therefore $\mu_{\mathrm{A}}(\mathrm{x}, \mathrm{q}) \geq \mu_{\mathrm{A}}(0, \mathrm{q})$

Also $\quad \mu_{A}(0, q) \geq \mu_{A}(x, q)$ [Since A is an IQFI of $X$ ]

Hence $\mu_{A}(x, q)=\mu_{A}(0, q)$

Therefore $\mathrm{x} \in \mathrm{X}_{\mu}$ i.e. $\mathrm{x}^{*} \mathrm{y}, \mathrm{y} \in \mathrm{X}_{\mu} \Rightarrow \mathrm{x} \in \mathrm{X}_{\mu}$

Similarly we can prove $\mathrm{x}^{*} \mathrm{y}, \mathrm{y} \in \mathrm{X}_{v} \Rightarrow \mathrm{x} \in \mathrm{X}_{v}$

Hence $\mathrm{X}_{\mu}, \mathrm{X}_{v}$ are ideals of $\mathrm{X}$.

\section{Definition 3.3}

Let $A=\left\{\left\langle x, \mu_{A}(x, q), v_{A}(x, q)\right\rangle \mid x \in X, q \in Q\right\}$ be an IQF set in $X$ and let $t \in[0,1]$ then the set $U^{t}=\left\{x \in X \mid \mu_{A}(x, q) \geq t\right.$, $\mathrm{q} \in \mathrm{Q}\}$ and set $\mathrm{U}_{\mathrm{t}}=\left\{\mathrm{x} \in \mathrm{X} \mid v_{\mathrm{A}}(\mathrm{x}, \mathrm{q}) \leq \mathrm{t}, \mathrm{q} \in \mathrm{Q}\right\}$ are respectively called $\mu$ level t-cut and $\nu$ level t-cut of A.

\section{Theorem 3.6}

If an IQFS $A=\left\{\left\langle x, \mu_{A}(x, q), v_{A}(x, q)\right\rangle \mid x \in X, q \in Q\right\}$ is an IQF ideal of $X$, then two $\mu$ level t-cuts $U^{t_{1}}, U^{t_{1}}$ where $\left(t_{1}<\right.$ $\left.\mathrm{t}_{2}\right)$ of $\mathrm{A}$ are equal iff there is no $\mathrm{x} \in \mathrm{X}$ such that $\mathrm{t}_{1}<\mu_{\mathrm{A}}(\mathrm{x}, \mathrm{q})$ $<\mathrm{t}_{2}$.

Proof. Recall that $U^{t}=\left\{x \in X \mid \mu_{A}(x, q) \geq t, q \in Q\right\}$

Let $U^{t_{1}}=U^{t_{2}}$ where $\left(t_{1}<t_{2}\right)$ and there exists $x \in X$ such that $\mathrm{t}_{1}<\mu_{\mathrm{A}}(\mathrm{x}, \mathrm{q})<\mathrm{t}_{2}$. then $\mathrm{U}^{\mathrm{t}_{2}} \subset \mathrm{U}^{\mathrm{t}_{1}}$, then $\mathrm{x} \in \mathrm{U}^{\mathrm{t}_{1}}$ but $\mathrm{x} \notin$ $\mathrm{U}^{\mathrm{t}_{2}}$ which contradicts the fact that $\mathrm{U}^{\mathrm{t}_{1}}=\mathrm{U}^{\mathrm{t}_{2}}$. Hence there is no $\mathrm{x} \in \mathrm{X}$ such that $\mathrm{t}_{1}<\mu_{\mathrm{A}}(\mathrm{x}, \mathrm{q})<\mathrm{t}_{2}$.

Conversely,

Suppose there is no $x \in X$ such that $t_{1}<\mu_{A}(x, q)<t_{2}$, then $U^{t_{2}} \subset U^{t_{1}}\left(\right.$ since $\left.t_{1}<t_{2}\right)$. Again if $x \in U^{t_{1}}$ then $\mu_{A}(x, q) \geq$ $\mathrm{t}_{1}$ and by hypothesis we get $\mu_{\mathrm{A}}(\mathrm{x}, \mathrm{q}) \geq \mathrm{t}_{2} \Rightarrow U^{t_{1}} \subset U^{t_{2}}$. Hence $U^{t_{1}}=U^{t_{2}}$ 


\section{Theorem 3.7}

If an IQFS $A=\left\{\left\langle x, \mu_{A}(x, q), v_{A}(x, q)\right\rangle \mid x \in X, q \in Q\right\}$ is an IQF ideal of X, then two $v$ level t-cuts $U_{t_{1}}, U_{t_{2}}$ where $\left(\mathrm{t}_{1}<\right.$ $\mathrm{t}_{2}$ ) of $\mathrm{A}$ are equal iff there is no $\mathrm{x} \in \mathrm{X}$ such that $\mathrm{t}_{1}<v_{\mathrm{A}}(\mathrm{x}, \mathrm{q})<$ $\mathrm{t}_{2}$.

\section{Theorem 3.8}

If an IQFS $A=\left\{\left\langle x, \mu_{A}(x, q), v_{A}(x, q)>\right| x \in X, q \in Q\right\}$ is an IQF ideal of $X$, then the $\mu$ level t-cut and $v$ level t-cut of $A$ are ideal of $X$ for every $t \in[0,1]$ such that $t \in \operatorname{Im}\left(\mu_{A}\right) \cap$ $\operatorname{Im}\left(v_{\mathrm{A}}\right)$ which are respectively called $\mu$ level ideal and $v$ level ideal of $\mathrm{X}$.

Proof. Let $x^{*} y, y \in U^{t}$, then $\mu_{A}(x * y, q) \geq t, \mu_{A}(y, q) \geq t$

Therefore $\mu_{\mathrm{A}}(\mathrm{x}, \mathrm{q}) \geq \min \left\{\mu_{\mathrm{A}}(\mathrm{x} * \mathrm{y}, \mathrm{q}), \mu_{\mathrm{A}}(\mathrm{y}, \mathrm{q})\right\}$

$$
\begin{aligned}
& \geq \min \{t, t\}=t \\
& \Rightarrow \mu_{A}(x, q) \geq t \Rightarrow x \in U^{t} \\
& \text { Also } \quad \mu_{A}(0, q) \geq \mu_{A}(x, q) \geq t[\text { Since A is an IQFI of } X] \\
& \Rightarrow 0 \in U^{t}
\end{aligned}
$$

Hence $\mathrm{U}^{\mathrm{t}}$ is an ideal of $\mathrm{X}$, called $\mu$ level ideal of $\mathrm{X}$.

Similarly we can prove $U_{t}$ is an ideal of $X$, called $v$ level ideal of X.

\section{Theorem 3.9}

Let $A=\left\{\left\langle x, \mu_{A}(x, q), v_{A}(x, q)\right\rangle \mid x \in X, q \in Q\right\}$ be an IQF set in $X$, such that the set $U^{t}$, and $U_{t}$, are ideals of $X$, then $A=\{<$ $\left.\mathrm{x}, \mu_{\mathrm{A}}(\mathrm{x}, \mathrm{q}), v_{\mathrm{A}}(\mathrm{x}, \mathrm{q})>\mid \mathrm{x} \in \mathrm{X}, \mathrm{q} \in \mathrm{Q}\right\}$ is an IQF ideal of $X$.

Proof. Assume $A=\left(\mu_{A}, v_{A}\right)$ is not an IQFI of $X$. therefore there exist $a, b \in X$, such that

$\mu_{\mathrm{A}}(\mathrm{a}, \mathrm{q})<\min \left\{\mu_{\mathrm{A}}(\mathrm{a} * \mathrm{~b}, \mathrm{q}), \mu_{\mathrm{A}}(\mathrm{b}, \mathrm{q})\right\}$ holds

Let $\mathrm{t}=\left[\mu_{\mathrm{A}}(\mathrm{a}, \mathrm{q})+\min \left\{\mu_{\mathrm{A}}(\mathrm{a} * \mathrm{~b}, \mathrm{q}), \mu_{\mathrm{A}}(\mathrm{b}, \mathrm{q})\right\}\right] / 2$

Then $\mu_{\mathrm{A}}(\mathrm{a}, \mathrm{q})<\mathrm{t}<\min \left\{\mu_{\mathrm{A}}(\mathrm{a} * \mathrm{~b}, \mathrm{q}), \mu_{\mathrm{A}}(\mathrm{b}, \mathrm{q})\right\}$

Therefore $a^{*} b, b \in U^{t}$ but $\mu_{A}(a, q)<t$ i.e. a $\notin U^{t}$ which is a contradiction that $\mathrm{U}^{\mathrm{t}}$ is an ideal. Therefore we must have

$\mu_{A}(x, q) \geq \min \left\{\mu_{A}(x * y, q), \mu_{A}(y, q)\right\}$ for all $x, y \in X$.

Again suppose that $v_{\mathrm{A}}(\mathrm{a}, \mathrm{q})>\max \left\{v_{\mathrm{A}}(\mathrm{a} * \mathrm{~b}, \mathrm{q}), v_{\mathrm{A}}(\mathrm{b}, \mathrm{q})\right\}$ holds for some $a, b \in X$, take

$\mathrm{s}=\left[v_{\mathrm{A}}(\mathrm{a}, \mathrm{q})+\max \left\{v_{\mathrm{A}}(\mathrm{a} * \mathrm{~b}, \mathrm{q}), v_{\mathrm{A}}(\mathrm{b}, \mathrm{q})\right\}\right] / 2$

Therefore $v_{\mathrm{A}}(\mathrm{a}, \mathrm{q})>\mathrm{t}>\max \left\{\mathrm{v}_{\mathrm{A}}(\mathrm{a} * \mathrm{~b}, \mathrm{q}), \mathrm{v}_{\mathrm{A}}(\mathrm{b}, \mathrm{q})\right\}$

Therefore $\mathrm{a}^{*} \mathrm{~b}, \mathrm{~b} \in \mathrm{U}_{\mathrm{t}}$ but $\mu_{\mathrm{A}}(\mathrm{a}, \mathrm{q})>\mathrm{t}$ i.e. $\mathrm{a} \notin \mathrm{U}_{\mathrm{t}}$ which is a contradiction that $U_{t}$ is an ideal. Therefore we must have

$v_{A}(x, q) \leq \max \left\{v_{A}(x * y, q), v_{A}(y, q)\right\}$ for all $x, y \in X$.

Hence $\mathrm{A}=\left(\mu_{\mathrm{A}}, v_{\mathrm{A}}\right)$ is an IQFI of $\mathrm{X}$.

\section{Theorem 3.10}

Any ideal of $\mathrm{X}$ can be realized as both a $\mu$ level ideal and a $v$

level ideal for some intuitionistic Q-fuzzy ideal of X.

Proof. Let $I$ be an ideal of $X$ and let $A=\left\{<x, \mu_{A}(x, q), v_{A}(x\right.$, $q)>\mid x \in X, q \in Q\}$ be an IQFS in $X$ defined by

$\mu_{\mathrm{A}}(\mathrm{x}, \mathrm{q})= \begin{cases}t, & \text { if } x \in I, \\ u, & \text { otherwise, }\end{cases}$ and

$v_{A}(x, q)= \begin{cases}s, & \text { if } x \in I, \\ v, & \text { otherwise, }\end{cases}$

for all $\mathrm{x} \in \mathrm{X}$, where $\mathrm{t}$, $\mathrm{s}$ are fixed numbers in $(0,1)$ such that $0 \leq \mathrm{u} \leq \mathrm{t}, 0 \leq \mathrm{v} \leq \mathrm{s}, \mathrm{t}+\mathrm{s}<1$ and $\mathrm{u}+\mathrm{v}<1$. Let $\mathrm{x}, \mathrm{y} \in \mathrm{X}$, now if $\mathrm{x}^{*} \mathrm{y}, \mathrm{y} \in \mathrm{I}$, then $\mathrm{x} \in \mathrm{I}$

Therefore $\mu_{\mathrm{A}}(\mathrm{x}, \mathrm{q})=\min \left\{\mu_{\mathrm{A}}(\mathrm{x} * \mathrm{y}, \mathrm{q}), \mu_{\mathrm{A}}(\mathrm{y}, \mathrm{q})\right\}=\mathrm{t}$ and

$$
v_{\mathrm{A}}(\mathrm{x}, \mathrm{q})=\max \left\{v_{\mathrm{A}}(\mathrm{x} * \mathrm{y}, \mathrm{q}), v_{\mathrm{A}}(\mathrm{y}, \mathrm{q})\right\}=\mathrm{s}
$$

and if at least one of $x^{*} y$ and $y$ does not belong to $I$, then at least one of $\mu_{\mathrm{A}}(\mathrm{x} * \mathrm{y}, \mathrm{q})$ and $\mu_{\mathrm{A}}(\mathrm{y}, \mathrm{q})$ is equal to $\mathrm{u}$ and at least one of $v_{\mathrm{A}}(\mathrm{x} * \mathrm{y}, \mathrm{q})$ and $v_{\mathrm{A}}(\mathrm{y}, \mathrm{q})$ is equal to $\mathrm{v}$, therefore

$$
\mu_{\mathrm{A}}(\mathrm{x}, \mathrm{q}) \geq \mathrm{u}=\min \left\{\mu_{\mathrm{A}}(\mathrm{x} * \mathrm{y}, \mathrm{q}), \mu_{\mathrm{A}}(\mathrm{y}, \mathrm{q})\right\}
$$$$
v_{\mathrm{A}}(\mathrm{x}, \mathrm{q}) \leq \mathrm{v}=\max \left\{v_{\mathrm{A}}(\mathrm{x} * \mathrm{y}, \mathrm{q}), v_{\mathrm{A}}(\mathrm{y}, \mathrm{q})\right\}
$$

Hence $\mathrm{A}=\left(\mu_{\mathrm{A}}, v_{\mathrm{A}}\right)$ is an IQFI of $\mathrm{X}$ and $\mathrm{I}=\mathrm{Ut}^{\mathrm{t}}=\mathrm{U}_{\mathrm{t}}$.

\section{Theorem 3.11}

An IQFS $A=\left\{\left\langle x, \mu_{A}(x, q), v_{A}(x, q)\right\rangle \mid x \in X, q \in Q\right\}$ is an IQF ideal of $\mathrm{X}$ iff the Q-fuzzy sets $\mu_{\mathrm{A}}$ and $\bar{v}_{\mathrm{A}}$ are Q-fuzzy ideals of $\mathrm{X}$.

Proof. Let $A=\left\{\left\langle x, \mu_{A}(x, q), v_{A}(x, q)\right\rangle \mid x \in X, q \in Q\right\}$ be an IQF ideal of $X$ Clearly $\mu_{A}$ is a $Q$-fuzzy ideal of X. Now

$\bar{v}_{\mathrm{A}}(0, \mathrm{q})=1-v_{\mathrm{A}}(0, \mathrm{q}) \geq 1-v_{\mathrm{A}}(\mathrm{x}, \mathrm{q})=\bar{v}_{\mathrm{A}}(\mathrm{x}, \mathrm{q})$ and for all $\mathrm{x}, \mathrm{y} \in \mathrm{X}, \bar{v}_{\mathrm{A}}(\mathrm{x}, \mathrm{q})$

$$
\begin{aligned}
& =1-v_{\mathrm{A}}(\mathrm{x}, \mathrm{q}) \\
& \geq 1-\max \left[v_{\mathrm{A}}(\mathrm{x} * \mathrm{y}, \mathrm{q}), v_{\mathrm{A}}(\mathrm{y}, \mathrm{q})\right] \\
& =\min \left\{\left(1-v_{\mathrm{A}}(\mathrm{x} * \mathrm{y}, \mathrm{q})\right),\left(1-v_{\mathrm{A}}(\mathrm{y}, \mathrm{q})\right)\right\} \\
& =\min \left\{\bar{v}_{\mathrm{A}}(\mathrm{x} * \mathrm{y}, \mathrm{q}), \bar{v}_{\mathrm{A}}(\mathrm{y}, \mathrm{q})\right\} \text { therefore } \bar{v}_{\mathrm{A}} \text { is a }
\end{aligned}
$$
q-fuzzy ideal of $X$.

Conversely suppose $\mu_{\mathrm{A}}$ and $\bar{\nu}_{\mathrm{A}}$ are Q-fuzzy ideal of $\mathrm{X}$. to prove $\mathrm{A}=\left\{\left\langle\mathrm{x}, \mu_{\mathrm{A}}(\mathrm{x}, \mathrm{q}), v_{\mathrm{A}}(\mathrm{x}, \mathrm{q})\right\rangle \mid \mathrm{x} \in \mathrm{X}, \mathrm{q} \in \mathrm{Q}\right\}$ is an intuitionistic Q-fuzzy ideal of X. Now

$$
\begin{aligned}
& 1-v_{\mathrm{A}}(0, \mathrm{q})=\bar{v}_{\mathrm{A}}(0, \mathrm{q}) \geq \bar{v}_{\mathrm{A}}(\mathrm{x}, \mathrm{q})=1-v_{\mathrm{A}}(\mathrm{x}, \mathrm{q}) \\
& \Rightarrow v_{\mathrm{A}}(0, \mathrm{q}) \leq v_{\mathrm{A}}(\mathrm{x}, \mathrm{q}) \\
& 1-v_{\mathrm{A}}(\mathrm{x}, \mathrm{q})=\bar{v}_{\mathrm{A}}(\mathrm{x}, \mathrm{q}) \geq \min \left\{\bar{v}_{\mathrm{A}}(\mathrm{x} * \mathrm{y}, \mathrm{q}), \bar{v}_{\mathrm{A}}(\mathrm{y}, \mathrm{q})\right\} \\
& =\min \left\{1-v_{\mathrm{A}}(\mathrm{x} * \mathrm{y}, \mathrm{q}), 1-v_{\mathrm{A}}(\mathrm{y}, \mathrm{q})\right\} \\
& =1-\max \left\{v_{\mathrm{A}}(\mathrm{x} * \mathrm{y}, \mathrm{q}), v_{\mathrm{A}}(\mathrm{y}, \mathrm{q})\right\} \\
& \Rightarrow v_{\mathrm{A}}(\mathrm{x}, \mathrm{q}) \leq \max \left\{v_{\mathrm{A}}(\mathrm{x} * \mathrm{y}, \mathrm{q}), v_{\mathrm{A}}(\mathrm{y}, \mathrm{q})\right\} \text { for all } \mathrm{x}, \mathrm{y} \in \mathrm{X} .
\end{aligned}
$$

Hence $\mathrm{A}$ is an intuitionistic Q-fuzzy ideal of $\mathrm{X}$.

\section{Theorem 3.12}

An IQFS $A=\left\{\left\langle x, \mu_{A}(x, q), v_{A}(x, q)>\right| x \in X, q \in Q\right\}$ is an IQF ideal of $X$ iff $\square \mathrm{A}=\left\{<\mathrm{x}, \mu_{\mathrm{A}}(\mathrm{x}, \mathrm{q}), \quad \bar{\mu}_{\mathrm{A}}(\mathrm{x}, \mathrm{q})>\mid \mathrm{x} \in \mathrm{X}\right.$, $\mathrm{q} \in \mathrm{Q}\}$ and $\diamond \mathrm{A}=\left\{\left\langle\mathrm{x}, \bar{v}_{\mathrm{A}}(\mathrm{x}, \mathrm{q}), v_{\mathrm{A}}(\mathrm{x}, \mathrm{q})\right\rangle \mid \mathrm{x} \in \mathrm{X}, \mathrm{q} \in \mathrm{Q}\right\}$ are also IQF ideal of $X$.

Proof.For $\square \mathrm{A}$, it is enought to show that $\bar{\mu}_{\mathrm{A}}(\mathrm{x}, \mathrm{q})$ satisfies the second part of the conditions Now

$\bar{\mu}_{\mathrm{A}}(0, \mathrm{q})=1-\mu_{\mathrm{A}}(0, \mathrm{q}) \leq 1-\mu_{\mathrm{A}}(\mathrm{x}, \mathrm{q}) \leq \bar{\mu}_{\mathrm{A}}(\mathrm{x}, \mathrm{q})$ 


$$
\begin{aligned}
\bar{\mu}_{\mathrm{A}}(\mathrm{x}, \mathrm{q}) & =1-\mu_{\mathrm{A}}(\mathrm{x}, \mathrm{q}) \leq 1-\min \left\{\mu_{\mathrm{A}}(\mathrm{x} * \mathrm{y}, \mathrm{q}), \mu_{\mathrm{A}}(\mathrm{y}, \mathrm{q})\right\} \\
& =\max \left\{1-\mu_{\mathrm{A}}(\mathrm{x} * \mathrm{y}, \mathrm{q}), 1-\mu_{\mathrm{A}}(\mathrm{y}, \mathrm{q})\right\} \\
& =\max \left\{\bar{\mu}_{\mathrm{A}}(\mathrm{x} * \mathrm{y}, \mathrm{q}), \bar{\mu}_{\mathrm{A}}(\mathrm{y}, \mathrm{q})\right\} \\
\bar{\mu}_{\mathrm{A}}(\mathrm{x}, \mathrm{q}) & =\max \left\{\bar{\mu}_{\mathrm{A}}(\mathrm{x} * \mathrm{y}, \mathrm{q}), \bar{\mu}_{\mathrm{A}}(\mathrm{y}, \mathrm{q})\right\}
\end{aligned}
$$

Hence $\square \mathrm{A}$ is an IQF ideal of $\mathrm{X}$.

For $\nabla \mathrm{A}$, it is enought to show that $\bar{v}_{\mathrm{A}}(\mathrm{x}, \mathrm{q})$ satisfies the first part of the conditions

$$
\begin{aligned}
& \text { Now } \bar{v}_{\mathrm{A}}(0, \mathrm{q})=1-v_{\mathrm{A}}(0, \mathrm{q}) \geq 1-v_{\mathrm{A}}(\mathrm{x}, \mathrm{q}) \geq \bar{v}_{\mathrm{A}}(\mathrm{x}, \mathrm{q}) \\
& \begin{aligned}
\bar{v}_{\mathrm{A}}(\mathrm{x}, \mathrm{q})= & 1-v_{\mathrm{A}}(\mathrm{x}, \mathrm{q}) \\
\geq & 1-\max \left\{v_{\mathrm{A}}(\mathrm{x} * \mathrm{y}, \mathrm{q}), v_{\mathrm{A}}(\mathrm{y}, \mathrm{q})\right\} \\
& =\min \left\{1-v_{\mathrm{A}}(\mathrm{x} * \mathrm{y}, \mathrm{q}), 1-v_{\mathrm{A}}(\mathrm{y}, \mathrm{q})\right\}= \\
& =\min \left\{\bar{v}_{\mathrm{A}}(\mathrm{x} * \mathrm{y}, \mathrm{q}), \bar{v}_{\mathrm{A}}(\mathrm{y}, \mathrm{q})\right\} \\
\bar{v}_{\mathrm{A}}(\mathrm{x}, \mathrm{q}) & =\min \left\{\bar{v}_{\mathrm{A}}(\mathrm{x} * \mathrm{y}, \mathrm{q}), \bar{v}_{\mathrm{A}}(\mathrm{y}, \mathrm{q})\right\}
\end{aligned}
\end{aligned}
$$

Hence $\diamond \mathrm{A}$ is an IQF ideal of $\mathrm{X}$.

\section{Theorem 3.13}

An IQFS $A=\left\{\left\langle x, \mu_{A}(x, q), v_{A}(x, q)>\right| x \in X, q \in Q\right\}$ is an IQF closed ideal of $X$ iff $\square \mathrm{A}=\left\{\left\langle\mathrm{x}, \mu_{\mathrm{A}}(\mathrm{x}, \mathrm{q}), \bar{\mu}_{\mathrm{A}}(\mathrm{x}, \mathrm{q})>\right| \mathrm{x}\right.$ $\in X, q \in Q\}$ and $\diamond \mathrm{A}=\left\{\left\langle\mathrm{x}, \bar{v}_{\mathrm{A}}(\mathrm{x}, \mathrm{q}), v_{\mathrm{A}}(\mathrm{x}, \mathrm{q})\right\rangle \mid \mathrm{x} \in \mathrm{X}, \mathrm{q} \in\right.$ $\mathrm{Q}\}$ are also IQF closed ideal of $\mathrm{X}$.

\section{INVESTIGATION OF IQFI UNDER HOMOMORPHISM}

\section{Definition 4.1}

A mapping $\mathrm{f}: \mathrm{X} \rightarrow \mathrm{Y}$ of algebras is called a homomorphism if $\mathrm{f}(\mathrm{x} * \mathrm{y})=\mathrm{f}(\mathrm{x}) * \mathrm{f}(\mathrm{y}) \forall \mathrm{x}, \mathrm{y} \in X$.

\section{Theorem 4.1}

Let $\mathrm{X}$ and $\mathrm{Y}$ be two BG-algebras and $\mathrm{f}: \mathrm{X} \rightarrow \mathrm{Y}$ be a homomorphism Then $\mathrm{f}(0)=0$.

Proof. Let $\mathrm{x} \in \mathrm{X}$ therefore $\mathrm{f}(\mathrm{x}) \in \mathrm{Y}$

Now $f(0)=f(x * x)=f(x) * f(x)=0 * 0=0$.

Let $\mathrm{f}: \mathrm{X} \rightarrow \mathrm{Y}$ be a homomprphism of BG- algebras for any IQFS $A=\left(\mu_{A}, v_{A}\right)$ of $Y$ we define a new IQFS $A^{f}=<$ $\mu_{A}^{f}, v_{A}^{f}>$ in $X$ by $\mu_{A}^{f}(x, q)=\mu_{A}(f(x), q)$ and $v_{A}^{f}(x, q)=$ $v_{\mathrm{A}}(\mathrm{f}(\mathrm{x}), \mathrm{q})$ for all $\mathrm{x} \in \mathrm{X}$.

\section{Theorem 4.2}

Let $\mathrm{f}: \mathrm{X} \rightarrow \mathrm{Y}$ be a homomorphism of BG-algebras .If an IQFS $A=\left(\mu_{\mathrm{A}}, v_{\mathrm{A}}\right)$ of $\mathrm{Y}$ is an IQF ideal of $Y$, then the IQFS $A^{f}=\left\langle\mu_{A}^{f}, v_{A}^{f}>\right.$ in $X$ is an IQFI of $X$.

Proof. Here

$\mu_{A}^{f}(x, q)=\mu_{A}(f(x), q) \leq \mu_{A}(0, q)=\mu_{A}(f(0), q)=\mu_{A}^{f}(0, q)$

i.e $\mu_{A}^{\mathrm{f}}(0, q) \geq \mu_{A}^{\mathrm{f}}(\mathrm{x}, \mathrm{q})$

Again

$v_{A}^{f}(x, q)=v_{A}(f(x), q) \geq v_{A}(0, q) \geq v_{A}(f(0), q)=v_{A}^{f}(0, q)$

$v_{A}{ }^{f}(0, q) \leq v_{A}{ }^{f}(x, q)$ for all $x \in X$

Again let $x, y \in X$, then

$\min \left\{\mu_{\mathrm{A}}^{\mathrm{f}}(\mathrm{x} * \mathrm{y}, \mathrm{q}), \mu_{\mathrm{A}}^{\mathrm{f}}(\mathrm{y}, \mathrm{q})\right\}$

$=\min \left\{\mu_{\mathrm{A}}(\mathrm{f}(\mathrm{x} * \mathrm{y}), \mathrm{q}), \mu_{\mathrm{A}}(\mathrm{f}(\mathrm{y}), \mathrm{q})\right\}$

$=\min \left\{\mu_{A}(f(x) * f(y), q), \mu_{A}(f(y), q)\right\}$ $\leq \mu_{\mathrm{A}}(\mathrm{f}(\mathrm{x}), \mathrm{q})=\mu^{\mathrm{f}}(\mathrm{x}, \mathrm{q})$

i.e. $\mu^{\mathrm{f}}(\mathrm{x}, \mathrm{q}) \geq \min \left\{\mu^{\mathrm{f}}(\mathrm{x} * \mathrm{y}, \mathrm{q}), \mu^{\mathrm{f}}(\mathrm{y}, \mathrm{q})\right\}$

And

$\max \left\{v_{\mathrm{A}}^{\mathrm{f}}(\mathrm{x} * \mathrm{y}, \mathrm{q}), v_{\mathrm{A}}^{\mathrm{f}}(\mathrm{y}, \mathrm{q})\right\}$

$=\max \left\{v_{\mathrm{A}}(\mathrm{f}(\mathrm{x} * \mathrm{y}), \mathrm{q}), v_{\mathrm{A}}(\mathrm{f}(\mathrm{y}), \mathrm{q})\right\}$

$=\max \left\{v_{\mathrm{A}}(\mathrm{f}(\mathrm{x}) * \mathrm{f}(\mathrm{y}), \mathrm{q}), v_{\mathrm{A}}(\mathrm{f}(\mathrm{y}), \mathrm{q})\right\}$

$\geq v_{\mathrm{A}}(\mathrm{f}(\mathrm{x}), \mathrm{q})=v^{\mathrm{f}}(\mathrm{x}, \mathrm{q})$

i.e. $v^{\mathrm{f}}(\mathrm{x}, \mathrm{q}) \leq \max \left\{v^{\mathrm{f}}(\mathrm{x} * \mathrm{y}, \mathrm{q}), v^{\mathrm{f}}(\mathrm{y}, \mathrm{q})\right\}$

Hence from (1),(2),(3) and (4) $A^{\mathrm{f}}=\left\langle\mu_{\mathrm{A}}{ }^{\mathrm{f}}, v_{\mathrm{A}}{ }^{\mathrm{f}}>\right.$ is an IQF ideal of $\mathrm{X}$.

\section{Theorem 4.3}

Let $\mathrm{f}: \mathrm{X} \rightarrow \mathrm{Y}$ be a epimomorphism of BG-algebras. Then $\mathrm{A}$ $=\left(\mu_{\mathrm{A}}, v_{\mathrm{A}}\right)$ be an IQFI in $\mathrm{Y}$ if $\mathrm{A}^{\mathrm{f}}=\left\langle\mu_{\mathrm{A}}{ }^{\mathrm{f}}, v_{\mathrm{A}}{ }^{\mathrm{f}}>\right.$ is an IQFI ideal of X.

Proof. For any $x \in Y$ there exists $a \in X$ such that $f(a)=x$ then $\mu_{A}(x, q)=\mu_{A}(f(a), q)=\mu^{f}(a, q) \leq \mu^{f}(0, q)=\mu_{A}(f(0), q)=$ $\mu_{\mathrm{A}}(0, \mathrm{q})$

$$
\begin{aligned}
& v_{A}(x, q)=v_{A}(f(a), q)=v^{f}(a, q) \geq v^{f}(0, q)=v_{A}(f(0), q) \\
& =v_{A}(0, q)
\end{aligned}
$$

Let $x, y \in Y$,then $f(a)=x$ and $f(b)=y$ for some $a, b \in X$ then

$$
\begin{aligned}
& \mu_{A}(x, q)=\mu_{A}(f(a), q)=\mu_{A}^{f}(a, q) \\
& \geq \min \left\{\mu_{A}^{f}(a * b, q), \mu_{A}^{f}(b, q)\right\} \\
& =\min \left\{\mu_{A}(f(a * b), q), \mu_{A}(f(b), q)\right\} \\
& =\min \left\{\mu_{A}(f(a) * f(b), q), \mu_{A}(f(b), q)\right\} \\
& =\min \left\{\mu_{A}(x * y, q), \mu_{A}(y, q)\right\}
\end{aligned}
$$

and

$v_{\mathrm{A}}(\mathrm{x}, \mathrm{q})=v_{\mathrm{A}}(\mathrm{f}(\mathrm{a}), \mathrm{q})=v_{\mathrm{A}}{ }^{\mathrm{f}}(\mathrm{a}, \mathrm{q})$

$\leq \max \left\{v_{\mathrm{A}}{ }^{\mathrm{f}}(\mathrm{a} * \mathrm{~b}, \mathrm{q}), v_{\mathrm{A}}{ }^{\mathrm{f}}(\mathrm{b}, \mathrm{q})\right\}$

$=\max \left\{v_{\mathrm{A}} \mathrm{f}((\mathrm{a} * \mathrm{~b}), \mathrm{q}), v_{\mathrm{A}}(\mathrm{f}(\mathrm{b}), \mathrm{q})\right\}$

$=\max \left\{v_{\mathrm{A}}(\mathrm{f}(\mathrm{a}) * \mathrm{f}(\mathrm{b}), \mathrm{q}), v_{\mathrm{A}}(\mathrm{f}(\mathrm{b}), \mathrm{q})\right\}$

$=\max \left\{v_{\mathrm{A}}(\mathrm{x} * \mathrm{y}, \mathrm{q}), v_{\mathrm{A}}(\mathrm{y}, \mathrm{q})\right\}$

Hence from above $\mathrm{A}=\left(\mu_{\mathrm{A}}, v_{\mathrm{A}}\right)$ be an IQFI in $\mathrm{Y}$.

\section{PRODUCT OF IQFI OF BG-ALGEBRAS}

\section{Theorem 5.1}

Let $\mathrm{X}$ be a BG-algebra, then the Cartesian product $\mathrm{X} \times \mathrm{X}$.= $\{(x, y) \mid x, y \in X\}$ is also a BG-algebra under the binary operation $*$ defined in $X \times X$ by $(x, y) *(p, q)=(x * p, y * q)$ for all $(x, y),(p, q) \in X \times X$.

Proof. Clearly $(0,0) \in \mathrm{X} \times \mathrm{X}$

(i) $(x, y) *(x, y)=\left(x * x, y^{*} y\right)=(0,0)$

(ii) $(\mathrm{x}, \mathrm{y}) *(0,0)=(\mathrm{x} * 0, \mathrm{y} * 0)=(\mathrm{x}, \mathrm{y})$

(iii) $\{(\mathrm{x}, \mathrm{y}) *(\mathrm{p}, \mathrm{q})\} *\{(0,0) *(\mathrm{p}, \mathrm{q})\}=(\mathrm{x} * \mathrm{p}, \mathrm{y} * \mathrm{q}) *(0 * \mathrm{p}, 0 * \mathrm{q})$

$=\{(\mathrm{x} * \mathrm{p}) *(0 * \mathrm{p}),(\mathrm{y} * \mathrm{q}) *(0 * \mathrm{q})\}$

$=(\mathrm{x}, \mathrm{y})$

Which shows that $\left(\mathrm{X} \times \mathrm{X},(0,0),{ }^{*}\right)$ is a BG-algebra. 


\section{Definition 5.1}

Let $A=\left(\mu_{A}, v_{A}\right)$ and $B=\left(\mu_{B}, v_{B}\right)$ be two IQF sets of BGalgebra $\mathrm{X}$,then their Cartesian product is denoted by $\mathrm{A} \times \mathrm{B}=$ $\left(\mathrm{X} \times \mathrm{X}, \mu_{\mathrm{A}} \times \mu_{\mathrm{B}}, v_{\mathrm{A}} \times v_{\mathrm{B}}\right)$ and defined by

$\left(\mu_{\mathrm{A}} \times \mu_{\mathrm{B}}\right)((\mathrm{x}, \mathrm{y}), \mathrm{q})=\min \left\{\mu_{\mathrm{A}}(\mathrm{x}, \mathrm{q}), \mu_{\mathrm{B}}(\mathrm{y}, \mathrm{q})\right\}$

$\left(v_{\mathrm{A}} \times v_{\mathrm{B}}\right)((\mathrm{x}, \mathrm{y}), \mathrm{q})=\max \left\{v_{\mathrm{A}}(\mathrm{x}, \mathrm{q}), v_{\mathrm{B}}(\mathrm{y}, \mathrm{q})\right\}$

Where $\mu_{\mathrm{A}} \times \mu_{\mathrm{B}}: \mathrm{X} \times \mathrm{X} \rightarrow\left[\begin{array}{ll}0 & 1\end{array}\right]$

and $v_{\mathrm{A}} \times v_{\mathrm{B}}: \mathrm{X} \times \mathrm{X} \rightarrow\left[\begin{array}{l}0 \\ 1\end{array}\right]$ for all $\mathrm{x}, \mathrm{y} \in \mathrm{X}$.

\section{Theorem 5.2}

Let $\mathrm{A}=\left(\mu_{\mathrm{A}}, v_{\mathrm{A}}\right)$ and $\mathrm{B}=\left(\mu_{\mathrm{B}}, v_{\mathrm{B}}\right)$ be two IQF ideals of BGalgebra $X$, then $A \times B$ is an IQF ideal of $X \times X$

Proof. For an $(x, y) \in X \times X$

we have $\left(\mu_{A} \times \mu_{B}\right)((0,0), q)=\min \left\{\mu_{A}(0, q), \mu_{B}(0, q)\right\}$

$$
\begin{aligned}
& \geq \min \left\{\mu_{\mathrm{A}}(\mathrm{x}, \mathrm{q}), \mu_{\mathrm{B}}(\mathrm{y}, \mathrm{q})\right\} \\
& =\left(\mu_{\mathrm{A}} \times \mu_{\mathrm{B}}\right)((\mathrm{x}, \mathrm{y}), \mathrm{q})
\end{aligned}
$$

$\left(v_{\mathrm{A}} \times v_{\mathrm{B}}\right)((0,0), \mathrm{q})=\max \left\{v_{\mathrm{A}}(0, \mathrm{q}), v_{\mathrm{B}}(0, \mathrm{q})\right\}$

$$
\begin{aligned}
& \leq \max \left\{v_{\mathrm{A}}(\mathrm{x}, \mathrm{q}), v_{\mathrm{B}}(\mathrm{y}, \mathrm{q})\right\} \\
& =\left(v_{\mathrm{A}} \times v_{\mathrm{B}}\right)((\mathrm{x}, \mathrm{y}), \mathrm{q}) \quad \forall \mathrm{x}, \mathrm{y} \in \mathrm{X}
\end{aligned}
$$

For $\left(\mathrm{x}_{1}, \mathrm{y}_{1}\right),\left(\mathrm{x}_{2} \mathrm{y}_{2}\right) \in \mathrm{X} \times \mathrm{X}$ then

$\left(\mu_{\mathrm{A}} \times \mu_{\mathrm{B}}\right)\left(\left(\mathrm{x}_{1}, \mathrm{y}_{1}\right), \mathrm{q}\right)=\min \left\{\mu_{\mathrm{A}}\left(\mathrm{x}_{1}, \mathrm{q}\right), \mu_{\mathrm{B}}\left(\mathrm{y}_{1}, \mathrm{q}\right)\right\}$

$\geq \min \left\{\min \left\{\mu_{\mathrm{A}}\left(\mathrm{x}_{1} * \mathrm{x}_{2}, \mathrm{q}\right), \mu_{\mathrm{A}}\left(\mathrm{x}_{2}, \mathrm{q}\right)\right\}, \min \left\{\mu_{\mathrm{A}}\left(\mathrm{y}_{1} * \mathrm{y}_{2}, \mathrm{q}\right), \mu_{\mathrm{A}}\left(\mathrm{y}_{2}, \mathrm{q}\right)\right\}\right\}$

$=\min \left\{\min \left\{\mu_{\mathrm{A}}\left(\mathrm{x}_{1} * \mathrm{x}_{2}, \mathrm{q}\right), \mu_{\mathrm{A}}\left(\mathrm{y}_{1} * \mathrm{y}_{2}, \mathrm{q}\right)\right\}, \min \left\{\mu_{\mathrm{A}}\left(\mathrm{x}_{2}, \mathrm{q}\right), \mu_{\mathrm{A}}\left(\mathrm{y}_{2}, \mathrm{q}\right)\right\}\right\}$

$=\min \left\{\left(\mu_{\mathrm{A}} \times \mu_{\mathrm{B}}\right)\left(\left(\mathrm{x}_{1} * \mathrm{x}_{2}, \mathrm{y}_{1} * \mathrm{y}_{2}\right), \mathrm{q}\right),\left(\mu_{\mathrm{A}} \times \mu_{\mathrm{B}}\right)\left(\left(\mathrm{x}_{2}, \mathrm{y}_{2}\right), \mathrm{q}\right)\right\}$

$=\min \left\{\left(\mu_{\mathrm{A}} \times \mu_{\mathrm{B}}\right)\left(\left(\left(\mathrm{x}_{1}, \mathrm{y}_{1}\right) *\left(\mathrm{x}_{2}, \mathrm{y}_{2}\right)\right), \mathrm{q}\right),\left(\mu_{\mathrm{A}} \times \mu_{\mathrm{B}}\right)\left(\left(\mathrm{x}_{2}, \mathrm{y}_{2}\right), \mathrm{q}\right)\right\}$

Again

$\left(v_{\mathrm{A}} \times v_{\mathrm{B}}\right)\left(\left(\mathrm{x}_{1}, \mathrm{y}_{1}\right), \mathrm{q}\right)=\max \left\{v_{\mathrm{A}}\left(\mathrm{x}_{1}, \mathrm{q}\right), v_{\mathrm{B}}\left(\mathrm{y}_{1}, \mathrm{q}\right)\right\}$

$\leq \max \left\{\max \left\{v_{\mathrm{A}}\left(\mathrm{x}_{1} * \mathrm{x}_{2}, \mathrm{q}\right), v_{\mathrm{A}}\left(\mathrm{x}_{2}, \mathrm{q}\right)\right\}, \max \left\{v_{\mathrm{A}}\left(\mathrm{y}_{1} * \mathrm{y}_{2}, \mathrm{q}\right), v_{\mathrm{A}}\left(\mathrm{y}_{2}, \mathrm{q}\right)\right\}\right\}$

$=\max \left\{\max \left\{v_{\mathrm{A}}\left(\mathrm{x}_{1} * \mathrm{x}_{2}, \mathrm{q}\right), v_{\mathrm{A}}\left(\mathrm{y}_{1} * \mathrm{y}_{2}, \mathrm{q}\right)\right\}, \max \left\{v_{\mathrm{A}}\left(\mathrm{x}_{2}, \mathrm{q}\right), v_{\mathrm{A}}\left(\mathrm{y}_{2}, \mathrm{q}\right)\right\}\right\}$

$=\max \left\{\left(v_{\mathrm{A}} \times v_{\mathrm{B}}\right)\left(\left(\mathrm{x}_{1} * \mathrm{x}_{2}, \mathrm{y}_{1} * \mathrm{y}_{2}\right), \mathrm{q}\right),\left(v_{\mathrm{A}} \times v_{\mathrm{B}}\right)\left(\left(\mathrm{x}_{2}, \mathrm{y}_{2}\right), \mathrm{q}\right)\right\}$

$=\max \left\{\left(v_{\mathrm{A}} \times v_{\mathrm{B}}\right)\left(\left(\left(\mathrm{x}_{1}, \mathrm{y}_{1}\right) *\left(\mathrm{x}_{2}, \mathrm{y}_{2}\right)\right), \mathrm{q}\right),\left(v_{\mathrm{A}} \times v_{\mathrm{B}}\right)\left(\left(\mathrm{x}_{2}, \mathrm{y}_{2}\right), \mathrm{q}\right)\right\}$

Hence from above $\mathrm{A} \times \mathrm{B}$ is an IQF ideal of $\mathrm{BG}$-algebra $\mathrm{X} \times \mathrm{X}$.

\section{Theorem 5.3}

Let $A_{1}, A_{2}, \ldots A_{n}$ be an IQF ideals of BG-algebra $X$, then $A_{1}$ $\times A_{2} \times \ldots \times A_{n}$ is also an IQF ideal of BG-algebra $X \times X \ldots \times X$.

\section{Theorem 5.4}

Let $A=\left(\mu_{A}, v_{A}\right)$ and $B=\left(\mu_{B}, v_{B}\right)$ be two IQF sets of BGalgebra $X$, such that $A \times B$ is an IQF ideal of $X \times X$. then

(i) Either $\mu_{A}(0, q) \geq \mu_{A}(x, q)$ and $v_{A}(0, q) \leq v_{A}(x, q)$

or $\mu_{\mathrm{B}}(0, \mathrm{q}) \geq \mu_{\mathrm{B}}(\mathrm{x}, \mathrm{q})$ and $v_{\mathrm{B}}(0, \mathrm{q}) \leq v_{\mathrm{B}}(\mathrm{x}, \mathrm{q})$

(ii) If $\mu_{A}(0, q) \geq \mu_{A}(x, q)$ and $v_{A}(0, q) \leq v_{A}(x, q)$ for all $x$

$\in X$, then either $\mu_{B}(0, q) \geq \mu_{A}(x, q)$ and $v_{B}(0, q) \leq v_{A}(x, q)$ or $\mu_{\mathrm{B}}(0, \mathrm{q}) \geq \mu_{\mathrm{B}}(\mathrm{x}, \mathrm{q})$ and $v_{\mathrm{B}}(0, \mathrm{q}) \leq v_{\mathrm{B}}(\mathrm{x}, \mathrm{q})$

(iii)If $\mu_{\mathrm{B}}(0, \mathrm{q}) \geq \mu_{\mathrm{B}}(\mathrm{x}, \mathrm{q})$ and $v_{\mathrm{B}}(0, \mathrm{q}) \leq v_{\mathrm{B}}(\mathrm{x}, \mathrm{q})$ for all $\mathrm{x}$

$\in X$, then either $\mu_{A}(0, q) \geq \mu_{A}(x, q)$ and $v_{A}(0, q) \leq v_{A}(x, q)$ or $\mu_{\mathrm{A}}(0, \mathrm{q}) \geq \mu_{\mathrm{B}}(\mathrm{x}, \mathrm{q})$ and $v_{\mathrm{A}}(0, \mathrm{q}) \leq v_{\mathrm{B}}(\mathrm{x}, \mathrm{q})$

\section{Proof.}

(i) Assume $\mu_{\mathrm{A}}(\mathrm{x}, \mathrm{q})>\mu_{\mathrm{A}}(0, \mathrm{q})$ and $v_{\mathrm{A}}(\mathrm{x}, \mathrm{q})<v_{\mathrm{A}}(0, \mathrm{q})$ and $\mu_{\mathrm{B}}(\mathrm{y}, \mathrm{q})>\mu_{\mathrm{B}}(0, \mathrm{q})$ and $v_{\mathrm{B}}(\mathrm{y}, \mathrm{q})<v_{\mathrm{B}}(0, \mathrm{q})$ for some $\mathrm{x}, \mathrm{y} \in \mathrm{X}$.

Then

$$
\begin{aligned}
\left(\mu_{\mathrm{A}} \times \mu_{\mathrm{B}}\right)((\mathrm{x}, \mathrm{y}), \mathrm{q}) & =\min \left\{\mu_{\mathrm{A}}(\mathrm{x}, \mathrm{q}), \mu_{\mathrm{B}}(\mathrm{y}, \mathrm{q})\right\} \\
& >\min \left\{\mu_{\mathrm{A}}(0, \mathrm{q}), \mu_{\mathrm{B}}(0, \mathrm{q})\right\} \\
& =\left(\mu_{\mathrm{A}} \times \mu_{\mathrm{B}}\right)((0,0), \mathrm{q})
\end{aligned}
$$

And

$\left(v_{\mathrm{A}} \times v_{\mathrm{B}}\right)((\mathrm{x}, \mathrm{y}), \mathrm{q})=\max \left\{v_{\mathrm{A}}(\mathrm{x}, \mathrm{q}), v_{\mathrm{B}}(\mathrm{y}, \mathrm{q})\right\}$

$$
\begin{aligned}
& <\max \left\{v_{\mathrm{A}}(0, \mathrm{q}), v_{\mathrm{B}}(0, \mathrm{q})\right\} \\
& =\left(v_{\mathrm{A}} \times v_{\mathrm{B}}\right)((0,0), \mathrm{q})
\end{aligned}
$$

Which is a contradiction that $\mathrm{A} \times \mathrm{B}$ is an IQF ideal of $\mathrm{X} \times \mathrm{X}$.

Therefore either $\mu_{A}(0, q) \geq \mu_{A}(x, q)$ and $v_{A}(0, q) \leq v_{A}(x, q)$

or $\mu_{\mathrm{B}}(0, \mathrm{q}) \geq \mu_{\mathrm{B}}(\mathrm{x}, \mathrm{q})$ and $v_{\mathrm{B}}(0, \mathrm{q}) \leq v_{\mathrm{B}}(\mathrm{x}, \mathrm{q}) \forall \mathrm{x}, \mathrm{y} \in \mathrm{X}$

(ii) Assume $\mu_{\mathrm{B}}(0, \mathrm{q})<\mu_{\mathrm{A}}(\mathrm{x}, \mathrm{q})$ and $v_{\mathrm{B}}(0, \mathrm{q})>v_{\mathrm{A}}(\mathrm{x}, \mathrm{q})$ and $\mu_{\mathrm{B}}(0, \mathrm{q})<\mu_{\mathrm{B}}(\mathrm{y}, \mathrm{q})$ and $v_{\mathrm{B}}(0, \mathrm{q})>v_{\mathrm{B}}(\mathrm{y}, \mathrm{q}) \forall \mathrm{x}, \mathrm{y} \in \mathrm{X}$

Then $\left(\mu_{\mathrm{A}} \times \mu_{\mathrm{B}}\right)((0,0), \mathrm{q})=\min \left\{\mu_{\mathrm{A}}(0, \mathrm{q}), \mu_{\mathrm{B}}(0, \mathrm{q})\right\}$

$$
=\mu_{\mathrm{B}}(0, \mathrm{q})
$$

And $\left(\mu_{\mathrm{A}} \times \mu_{\mathrm{B}}\right)((\mathrm{x}, \mathrm{y}), \mathrm{q})=\min \left\{\mu_{\mathrm{A}}(\mathrm{x}, \mathrm{q}), \mu_{\mathrm{B}}(\mathrm{y}, \mathrm{q})\right\}$

$$
\begin{aligned}
> & \mu_{\mathrm{B}}(0, \mathrm{q}) \\
= & \left(\mu_{\mathrm{A}} \times \mu_{\mathrm{B}}\right)((0,0), \mathrm{q})
\end{aligned}
$$

Also

$$
\begin{aligned}
\left(v_{A} \times v_{B}\right)((0,0), q) & =\max \left\{v_{A}(0, q), v_{B}(0, q)\right\} \\
= & v_{B}(0, q)
\end{aligned}
$$

And $\left(v_{\mathrm{A}} \times v_{\mathrm{B}}\right)((\mathrm{x}, \mathrm{y}), \mathrm{q})=\max \left\{v_{\mathrm{A}}(\mathrm{x}, \mathrm{q}), v_{\mathrm{B}}(\mathrm{y}, \mathrm{q})\right\}$

$$
\begin{gathered}
<v_{B}(0, q) \\
=\left(v_{A} \times v_{B}\right)((0,0), q)
\end{gathered}
$$

Which is a contradiction that $\mathrm{A} \times \mathrm{B}$ is an IQF ideal of $\mathrm{X} \times \mathrm{X}$.

Hence either $\mu_{\mathrm{B}}(0, \mathrm{q}) \geq \mu_{\mathrm{A}}(\mathrm{x}, \mathrm{q})$ and $v_{\mathrm{B}}(0, \mathrm{q}) \leq v_{\mathrm{A}}(\mathrm{x}, \mathrm{q})$ or $\mu_{\mathrm{B}}(0, \mathrm{q}) \geq \mu_{\mathrm{B}}(\mathrm{x}, \mathrm{q})$ and $v_{\mathrm{B}}(0, \mathrm{q}) \leq v_{\mathrm{B}}(\mathrm{x}, \mathrm{q})$.

(iii) This proof is similar to case (ii) above.

\section{Theorem 5.5}

Let $A=\left(\mu_{A}, v_{A}\right)$ and $B=\left(\mu_{B}, v_{B}\right)$ be two IQF sets of BGalgebra $X$, such that $A \times B$ is an IQF ideal of $X \times X$. Then $A$ or $B$ is an IQF ideal of $X$.

Proof. First we prove that A is an IQF ideal of X.

Given $\mathrm{A} \times \mathrm{B}$ is an IQF ideal of $\mathrm{X} \times \mathrm{X}$ then by theorem 5.4

(i) Either $\mu_{A}(0, q) \geq \mu_{A}(x, q)$ and $v_{A}(0, q) \leq v_{A}(x, q)$

or $\mu_{\mathrm{B}}(0, \mathrm{q}) \geq \mu_{\mathrm{B}}(\mathrm{x}, \mathrm{q})$ and $v_{\mathrm{B}}(0, \mathrm{q}) \leq v_{\mathrm{B}}(\mathrm{x}, \mathrm{q})$

(ii)If $\mu_{A}(0, q) \geq \mu_{A}(x, q)$ and $v_{A}(0, q) \leq v_{A}(x, q)$ for all $x$

$\in X$, then either $\mu_{B}(0, q) \geq \mu_{A}(x, q)$ and $v_{B}(0, q) \leq v_{A}(x, q)$ or $\mu_{\mathrm{B}}(0, \mathrm{q}) \geq \mu_{\mathrm{B}}(\mathrm{x}, \mathrm{q})$ and $v_{\mathrm{B}}(0, \mathrm{q}) \leq v_{\mathrm{B}}(\mathrm{x}, \mathrm{q})$

Now $\mu_{A}(x, q)$

$=\min \left\{\mu_{A}(x, q), \mu_{B}(0, q)\right\}$ 


$$
\begin{aligned}
& =\left(\mu_{\mathrm{A}} \times \mu_{\mathrm{B}}\right)((\mathrm{x}, 0), \mathrm{q}) \\
& \geq \min \left\{\left(\mu_{\mathrm{A}} \times \mu_{\mathrm{B}}\right)((\mathrm{x}, 0) *(\mathrm{y}, 0), \mathrm{q}),\left(\mu_{\mathrm{A}} \times \mu_{\mathrm{B}}\right)((\mathrm{y}, 0), \mathrm{q})\right\} \\
& =\min \left\{\left(\mu_{\mathrm{A}} \times \mu_{\mathrm{B}}\right)((\mathrm{x} * \mathrm{y}, 0 * 0), \mathrm{q}),\left(\mu_{\mathrm{A}} \times \mu_{\mathrm{B}}\right)((\mathrm{y}, 0), \mathrm{q})\right\} \\
& =\min \left\{\left(\mu_{\mathrm{A}} \times \mu_{\mathrm{B}}\right)\left(\left(\mathrm{x}^{*} \mathrm{y}, 0\right), \mathrm{q}\right),\left(\mu_{\mathrm{A}} \times \mu_{\mathrm{B}}\right)((\mathrm{y}, 0), \mathrm{q})\right\} \\
& =\min \left\{\mu_{\mathrm{A}}\left(\mathrm{x}^{*} \mathrm{y}, \mathrm{q}\right), \mu_{\mathrm{A}}(\mathrm{y}, \mathrm{q})\right\} \\
& \mu_{\mathrm{A}}(\mathrm{x}, \mathrm{q}) \geq \min \left\{\mu_{\mathrm{A}}\left(\mathrm{x}^{*} \mathrm{y}, \mathrm{q}\right), \mu_{\mathrm{A}}(\mathrm{y}, \mathrm{q})\right\} \\
& \text { Again } \\
& v_{\mathrm{A}}(\mathrm{x}, \mathrm{q}) \\
& =\max \left\{v_{\mathrm{A}}(\mathrm{x}, \mathrm{q}), v_{\mathrm{B}}(0, \mathrm{q})\right\} \\
& =\left(v_{\mathrm{A}} \times v_{\mathrm{B}}\right)((\mathrm{x}, 0), \mathrm{q}) \\
& \leq \max \left\{\left(v_{\mathrm{A}} \times v_{\mathrm{B}}\right)((\mathrm{x}, 0) *(\mathrm{y}, 0), \mathrm{q}),\left(v_{\mathrm{A}} \times v_{\mathrm{B}}\right)((\mathrm{y}, 0), \mathrm{q})\right\} \\
& =\max \left\{\left(v_{\mathrm{A}} \times v_{\mathrm{B}}\right)\left(\left(\mathrm{x}^{*} \mathrm{y}, 0 * 0\right), \mathrm{q}\right),\left(v_{\mathrm{A}} \times v_{\mathrm{B}}\right)((\mathrm{y}, 0), \mathrm{q})\right\} \\
& =\max \left\{\left(v_{\mathrm{A}} \times v_{\mathrm{B}}\right)\left(\left(\mathrm{x}^{*} \mathrm{y}, 0\right), \mathrm{q}\right),\left(v_{\mathrm{A}} \times v_{\mathrm{B}}\right)((\mathrm{y}, 0), \mathrm{q})\right\} \\
& =\max \left\{v_{\mathrm{A}}(\mathrm{x} * \mathrm{y}, \mathrm{q}), v_{\mathrm{A}}(\mathrm{y}, \mathrm{q})\right\} \\
& v_{\mathrm{A}}(\mathrm{x}, \mathrm{q}) \leq \max \left\{v_{\mathrm{A}}(\mathrm{x} * \mathrm{y}, \mathrm{q}), v_{\mathrm{A}}(\mathrm{y}, \mathrm{q})\right\}
\end{aligned}
$$

Hence from above $\mathrm{A}$ is an IQF ideal of $\mathrm{X}$.

Similarly we can prove that $\mathrm{B}$ is an IQF ideal of X.

\section{Theorem 5.6}

Let $\mathrm{A}=\left(\mu_{\mathrm{A}}, v_{\mathrm{A}}\right)$ and $\mathrm{B}=\left(\mu_{\mathrm{B}}, v_{\mathrm{B}}\right)$ be two IQF closed ideals of $B G$-algebra $X$, then $A \times B$ is an IQF closed ideal of $X \times X$.

Proof. Here $\left(\mu_{\mathrm{A}} \times \mu_{\mathrm{B}}\right)((0,0) *(\mathrm{x}, \mathrm{y}), \mathrm{q})$

$$
\begin{aligned}
& =\left(\mu_{A} \times \mu_{B}\right)((0 * x, 0 * y), q) \\
& =\min \left\{\mu_{A}(0 * x, q), \mu_{B}(0 * y, q)\right\} \\
& \geq \min \left\{\mu_{A}(x, q), \mu_{B}(y, q)\right\} \\
& =\left(\mu_{A} \times \mu_{B}\right)((x, y), q)
\end{aligned}
$$

and

$$
\begin{aligned}
\left(v_{\mathrm{A}} \times v_{\mathrm{B}}\right) & ((0,0) *(\mathrm{x}, \mathrm{y}), \mathrm{q}) \\
& =\left(v_{\mathrm{A}} \times v_{\mathrm{B}}\right)((0 * \mathrm{x}, 0 * \mathrm{y}), \mathrm{q}) \\
& =\max \left\{v_{\mathrm{A}}(0 * \mathrm{x}, \mathrm{q}), v_{\mathrm{B}}(0 * \mathrm{y}, \mathrm{q})\right\} \\
& \leq \max \left\{v_{\mathrm{A}}(\mathrm{x}, \mathrm{q}), v_{\mathrm{B}}(\mathrm{y}, \mathrm{q})\right\} \\
& =\left(v_{\mathrm{A}} \times v_{\mathrm{B}}\right)((\mathrm{x}, \mathrm{y}), \mathrm{q})
\end{aligned}
$$

Hence $\mathrm{A} \times \mathrm{B}$ is an IQF closed ideal of BG-algebra $\mathrm{X} \times \mathrm{X}$.

\section{CONCLUSION}

In this paper, we have extended the intuitionistic fuzzy ideals of BG-algebra into intuitionistic Q-fuzzy ideals of BG-algebra and their products and in our opinion the research along this direction can be continue and in future we can apply this concept to some other algebraic structure. For further study, the following topics may be considered.

- Interval valued intuitionistic Q-fuzzy ideals in BG-algebras.

- $\quad$ Anti Q-fuzzy dot ideals of BG-algebras.

\section{REFERENCES}

[1] Zadeh, L.A.1965.Fuzzy sets, Inform. Control.vol.8,338353.

[2] Atanassov, K.T.1986.Intutionistic fuzzy sets, Fuzzy sets and Systems.vol.1,87-96

[3] Goguen, J.A.1967. L-Fuzzy sets, J. Math.Anal.Appl.18, $145-174$.

[4] Muthuraj, et al.2010. Anti Q-fuzzy BG-ideals in BGAlgebra, International Journal of Computer Applications, (0975- 8887) Volume 4 No-11,August 2010.

[5] Kim, K.H.2006.On intuitionistic Q-fuzzy semi prime ideals in semi group, Advances in fuzzy Mathematics1 (1), 15-21.

[6] Imai, Y. and Iseki, K.1966.On Axiom systems of Propositional calculi 15, Proc, Japan Academy, 42 (1966)19-22.

[7] Neggers J. and Kim H.S.2002. On B-algebras Math. Vensik, 54 (2002), 21-29.

[8] Kim C.B. and Kim H.S.2008.on BG-algebras Demonstratio Mathematica,Vol-41 No-3,497-505.

[9] Zarandi ,A. and Borumand Saeid, A.2005. On intutionistic fuzzy ideals of BG-algebras, World Academy of Sciences, Engineering and Technology, 5, 187-189.

[10] Senapati, T.Bhowmik, M.Pal, A.2012.Intuitionistic fuzzifications of ideals in BG-algebras, Mathematical Aeterna,Vol.2, no.9,761-778. 